\title{
The Value of Behavioral Economics for EU Judicial Decision-Making
}

\author{
Christoph K. Winter ${ }^{*}$
}

(Received 3 June 2019; accepted 27 July 2019)

\begin{abstract}
This Article analyzes the value of behavioral economics for EU judicial decision-making. The first part introduces the foundations of behavioral economics by focusing on cognitive illusions, prospect theory, and the underlying distinction between different processes of thought. The second part examines the influence of selected biases and heuristics, namely the anchoring effect, availability bias, zero-risk bias, and hindsight bias on diverse legal issues in EU law including, among others, the scope of the fundamental freedoms, the proportionality test as well as the roles of the Advocate General and Reporting Judge. The Article outlines how behavioral economic findings can be taken into account to improve judicial decisionmaking. Accordingly, the adaptation of judicial training concerning cognitive illusions, the establishment of a de minimis rule regarding the scope of the fundamental freedoms, and the use of economic models when determining the impact of certain measures on fundamental freedoms is suggested. Finally, an "unbiased jury" concentrating exclusively on specific factual issues such as causal connections within the proportionality test is necessary, if the hindsight bias is to be avoided. While it is of great importance to take behavioral economic findings into account, judicial decision-making is unlikely to become flawless based on natural intelligence. Despite bearing fundamental risks, artificial intelligence may provide means to achieve greater fairness, consistency, and legal certainty in the future.
\end{abstract}

Keywords: Judicial decision-making; behavioral law \& economics; cognitive biases; EU law; internal market law; proportionality; unbiased jury; Dassonville

\section{A. Introduction}

Article 2 of Protocol No. 3 on the Statute of the Court of Justice of the European Union states that "[b]efore taking up his duties each judge shall ... take an oath to perform his duties impartially and conscientiously...."

It has long been recognized that judges are not able to exclusively decide cases based on legal principles. Some legal realists suggest that the final judgment is influenced by the political or philosophical opinion of the judge. ${ }^{1}$ Others argue that the sex and race of the judge ${ }^{2}$ or the

\footnotetext{
${ }^{*}$ Assistant Professor, Instituto Tecnológico Autónomo de México (ITAM) Faculty of Law; Fellow, Harvard University Department of Psychology. Email: christoph_winter@fas.harvard.edu. ORCID ID: https://orcid.org/0000-0002-4903-7846. I am grateful to Oana Stefan, Samuel Young, and the participants at related presentations at Harvard Law School, King's College London, Princeton University's LEGS Seminar, and the United Nation's Codification Division for their comments and inspirations on this Article.

${ }^{1}$ See generally Felix S. Cohen, Transcendental Nonsense and the Functional Approach, 35 CoLUM. L. REV. 849 (1935); Jerome Frank, Courts on Trial: Myth and Reality in American Justice (1949) (providing a comprehensive analysis). See also Fred Rodell, Courts on Trial: Myth and Reality in American Justice, by Frank Jerome, 21 IND. L.J. 114, 114-19 (1949) (providing a review).
}

(C) The Author(s) 2020. Published by Cambridge University Press on behalf of the German Law Journal. This is an Open Access article, distributed under the terms of the Creative Commons Attribution licence (http://creativecommons.org/licenses/by/4.0/), which permits unrestricted re-use, distribution, and reproduction in any medium, provided the original work is properly cited. 
potential gain for his or her personal career $^{3}$ play a major role when making a judgment. From a more fundamental perspective, recent research by psychologists and behavioral economists shows that regardless of the political viewpoint, sex, or personal career opportunities, judges make systematic and predictable errors. ${ }^{4}$ Behavioral economics does not deny that judgments may be affected by political or other personal interests, rather it suggests that judgments are considerably influenced by rules of thumb-so-called heuristics and biases-wholly apart from political orientation and potential personal benefits..$^{5}$ As one is not able to control the application of such mental shortcuts, Article 2 of Protocol No. 3 may be overcharging human capabilities by prescribing to decide impartially and conscientiously.

So far, experiments have been conducted to test the impact of selected cognitive illusions to sentences in criminal law cases, the amount of damages awarded in civil law disputes, and judges' perceptions of diverse factual and legal issues covering cases from illegal immigration to fictional statutes regarding a Medical Marijuana Access Law. ${ }^{6}$ Yet presently, there are no studies concerning the application of EU law. ${ }^{7}$ At the same time, there is no reason to assume that EU judicial decisionmaking is exclusively shielded from cognitive biases. ${ }^{8}$ On the contrary, due to the underlying common neurological processes which are unlikely to change depending on the field of law, it can be expected that heuristics and biases have just as much influence. For instance, when assessing the importance of public security within the proportionality test, courts are very likely to overestimate the danger of a terrorist attack given that such events are generally overrepresented in mass media. ${ }^{9}$

The main goal of this Article is to raise awareness of the fact that there are infinite situations in which cognitive illusions affect judicial decisions. This fact needs to be acknowledged and consequently addressed if an impartial application of the law is to be upheld as required by Article 2 of Protocol No. 3 on the Statute of the Court of Justice of the European Union. Instead of conducting studies with regard to the influence of particular biases on one or more selected issues of European law, it seems beneficial at this stage of the academic debate to analyze the importance of behavioral economics for judicial decisions in EU law more broadly. In this way, it provides the basis for more targeted empirical testing. Arguably more importantly, the fact that there are infinite applications requires one to identify the underlying mechanisms of partially biased decision-making in order to develop more general means to mitigate or even eliminate cognitive biases rather than to focus solely on specific examples.

\footnotetext{
${ }^{2}$ See Gregory C. Sisk et al., Charting the Influences on the Judicial Mind: An Empirical Study of Judicial Reasoning, 73 N.Y.U. L. Rev. 1377, 1385-421 (1998). See generally Cassia Spohn, The Sentencing Decisions of Black and White Judges: Expected and Unexpected Similarities, 24 L. \& Soc'Y REV. 1198 (1990).

${ }^{3}$ See Richard A. Posner, What Do Judges and Justices Maximize? (The Same Things Everyone Else Does), 3 SUP. CT. ECON. Rev. 1, 1-28 (1993). See also Jonathan R. Macey, Judicial Preferences, Public Choice, and the Rules of Procedure, 23 J. LEGAL STUD. 627, 630-32 (1994).

${ }^{4}$ See Chris Guthrie et al., Inside the Judicial Mind, 86 Cornell L. Rev. 777-830 (2000) (providing further references).

${ }^{5}$ For an overview, see generally Thomas Gilovich et Al., Heuristics and Biases: The Psychology of Intuitive JUDGMENT (2002).

${ }^{6}$ See, e.g., Birte Englich et al., Playing Dice with Criminal Sentences: The Influence of Irrelevant Anchors on Experts' Judicial Decision Making, 32 Personality \& Soc. Psychol. Bull. 188, 188-200 (2006) (showing that rolling a pair of dice before handing down a sentence has a substantial influence on the sentence itself. De facto, the higher the number on the dice, the higher the sentence given by the court was). More recently, multiple studies have been conducted by Andrew J. Wistrich, Jeffrey J. Rachlinski, and Chris Guthrie. See e.g., Andrew J. Wistrich et al., Heart Versus Head: Do Judges Follow the Law or Follow Their Feelings?, 93 Tex. L. ReV. 855 (2015). See also Jeffrey J. Rachlinski \& Andrew J. Wistrich, Judging the Judiciary by the Numbers: Empirical Research on Judges, 13 AnN. Rev. L. \& Soc. ScI. 203 (2017); Andrew J. Wistrich et al., Implicit Bias in Judicial Decision Making, How It Affects Judgment and What Judges Can Do About It, in ENHANCING JUSTICE: REDUCING BIAs 87-130 (Sarah E. Redfield ed., 2018).

${ }^{7}$ See generally Anne-Lise Sibony \& Alberto Alemanno, The Emergence of Behavioral Policy-Making: A European Perspective, in Nudge ANd the LaW - A European Perspective 29 (Alberto Alemanno \& Anne-Lise Sibony eds., 2015).

${ }^{8}$ See id. at 29-30. In this regard, Sibony and Alemanno convincingly argue that "research conducted in the US almost surely would prove relevant as the core insights are linked to psychology and not to law." See also Guthrie et al., supra note 4, at 793-94 (arguing more generally for the application of cognitive illusions to judicial decision-making).

${ }^{9}$ See infra Section B.II. concerning the availability bias.
} 
Consequently, the first part of this Article will outline the historical emergence of behavioral economics, its major claims and underlying psychological assumptions. Moreover, behavioral economics as a field and the literature on cognitive biases in particular are not universally endorsed and its major critiques will have to be addressed as well. This discussion is necessary due to the fact that behavioral economics strongly deviates from traditional economic models based on rational decision-making and to understand why it will be a major - if not impossible — task to eliminate all biases. The second part will discuss how cognitive biases play an important role within judicial decision-making in EU law, thereby analyzing the effects of some cognitive illusions-namely the anchoring effect, availability bias, zero-risk bias, and hindsight bias.

To show the far-reaching impact of biases and their effects on innumerable aspects of the decision-making process, as well as to emphasize the overall value and importance of behavioral economic findings for understanding, evaluating, and improving EU judicial decision-making, the analysis of selected biases shall relate to diverse legal issues. To be precise, I will examine: (1) The role of the reporting judge and the Advocate General; (2) the balancing approach within the proportionality test; (3) the remoteness test; and (4) the long- lasting debate on the boundaries of the Dassonville formula. Needless to say, such vast areas will not be discussed holistically but only from a behavioral economic perspective.

The Article will finally suggest means to mitigate or even eliminate biases. More specifically, the analysis will argue favorably regarding the use of economic models to determine the impact on fundamental freedoms and the adaption of judicial training pertaining to behavioral economics, and cognitive psychology. Moreover, the establishment of a de minimis rule and an unbiased jury with regard to specific factual issues will be proposed. Although such changes are a necessary first step, it does not seem feasible to avoid or mitigate all cognitive illusions. For this reason, in the more or less distant future, judgments based partially on artificial—rather than naturalintelligence may well be considered a possible alternative or supplement to achieve greater fairness, consistency, and legal certainty provided the accompanying risks of such endeavor can and will be taken care of.

\section{B. Setting the Stage: The Foundations of Behavioral Economics}

The concept of the homo economicus assumes that human beings are self-interested and make rational decisions based on facts, evidence, and preferences. ${ }^{10}$ Human beings are therefore often considered as "resourceful, evaluating and maximizing." actual behavior of humans-especially when deciding under uncertainty-criticize this model. They suggest that, first, individuals do not merely act self-interested in terms of maximizing their own well-being and, second, they do not always decide rationally. In the following, these two major claims of behavioral economics will be briefly outlined by introducing studies concerning fairness games as well as prospect theory in order to form the basis for the more specific analysis of the effects of certain biases on EU judicial decision-making in the third part of this Article.

\section{Fairness Games}

Although the critique on the notion of rationality as part of the concept of the homo economicus has been far reaching, economic scholars of game theory have focused on disproving the element

\footnotetext{
${ }^{10}$ See James S. Coleman, Foundations of Social Theory 5 (1990).

${ }^{11} I d$. at 5. See generally Richard A. Posner, Are We One Self or Multiple Selves?, 3 LEgAL TheORY 24 (1997); Robert Frank, If Homo Economicus Could Chose His Own Utility Function, Would He Want One with a Conscience, 77 AM. ECON. REv. 602 (1987) (providing an evolutionary concept of the homo economicus).
} 
of a self-interested human being. Particularly, studies concerning the dictator and ultimatum game $^{12}$ illustrate that human beings may choose fair behavior over self-interest.

The classic ultimatum game is based on two players, who are unknown to each other. One of the participants will make an offer to the other participant on how to share a certain amount of money. If the other participant accepts the offer, then the money will be shared accordingly. If the other participant rejects the offer, then neither of the participants receive any money. Negotiations are not permitted. A self-interested, maximizing homo economicus would propose that she should get as much money as possible, whereas the responder of the offer will be left with as little money as possible. Moreover, the homo economicus on the receiving side of the offer would accept any offer, as it is better than receiving nothing at all. For example, if the tenderer makes an offer to share $\$ 100$ by proposing that she gets $\$ 99.99$, whereas the responder would get $\$ 0.01$, the responder would accept. Knowing that the responder acting as a homo economicus will accept even the tiniest amount, the tenderer has reason to offer such tiny amount in the first place. On the contrary to such prediction, studies routinely show that the most frequent offer is a $50 / 50$ split, ${ }^{13}$ whereas, on average, the offer is a $63 / 37$ split. ${ }^{14}$

Such studies do not prove that the tenderer values fairness over self-interest because she might simply be aware of the risk that the responder may reject the offer and-for this reason onlyoffers more than $\$ 0.01$. The experiment nevertheless shows that the responder does not act in accordance with the highest self-interest, for offers below $20 \%$ of the amount to split were routinely rejected. ${ }^{15}$ It is therefore argued that the receiver incorporates fairness considerations into her decision. ${ }^{16}$ At last, it should be noted that the absolute amount of the offered share does not make a difference. People in these studies did not behave more or less self-interested when the stakes were higher. Even when the offered amount was equal to wages of several months, individuals rejected offers on the same basis as individuals who were facing a relatively small amount of money. ${ }^{17}$

The experiment of the so-called dictator game focuses primarily on the player making the offer. In this scenario, the responder does not have the option to reject the offer. In fact, she is not able to act within the experiment at all. Although the concept of a self-interested human being suggests that the offeror will take $100 \%$ of the amount, only $36 \%$ of the proposers choose to do so, while $64 \%$ decide to give the other party some portion of the resources. ${ }^{18}$ Thus, the dictator game shows that human beings do not merely act self-interested, thereby shedding serious doubts on a crucial element of the concept of the homo economicus. The universal ${ }^{19}$ human desire to be fair leads to choices that significantly deviate from purely self-interested economic models. ${ }^{20}$

\footnotetext{
${ }^{12}$ See Werner Güth et al., An Experimental Analysis of Ultimatum Bargaining, 3 J. ECON. BEHAV. \& ORG. 367, 367-88 (1982) (providing an analysis of the game).

${ }^{13}$ See Max Bazerman \& Don A. Moore, Judgment in Managerial Decision Making 117 (7th ed. 2013).

${ }^{14}$ See generally Richard H. Thaler, Anomalies: The Ultimatum Game, 2 J. ECON. PERsP. 195 (1988). See also RICHARD H. Thaler, The Winner's Curse: Paradoxes and AnOmalies of Economic Life 21 (1994).

${ }^{15}$ See BAZERMAN \& MOORE, supra note 13 , at 117.

${ }^{16}$ See BAZERMAN \& MOORE, supra note 13 , at 117.

${ }^{17}$ See Steven J. Kachelmeier \& Mohamed Shehata, Examining Risk Preferences Under High Monetary Incentives: Experimental Evidence from the People's Republic of China, 82 AM. ECON. REV. 1120, 1120-41 (1992). See also Markus Englehrt, Behavioral Law and Economics: Eine kritische Einführung, in RECHT UND VERHALTEN 60, 72-130 (Christoph Engel et al. eds., 2007) (providing a summary of counter-arguments against the ultimatum game as a reliable study).

${ }^{18}$ See BAZERMAN \& MOORE, supra note 13, at 118.

${ }^{19}$ See Joseph Henrich et al., In Search of Homo Economicus: Behavioral Experiments in 15 Small-Scale Societies, 91 AM. ECON. REV. 73, 73-78 (2001). The authors conducted studies in fifteen global societies. Accordingly, it was found that, although the concept of fairness depends on cultural norms and may therefore differ among societies, fairness itself was always found to be a crucial factor which was taken into account while making a decision.

${ }^{20}$ See BAZERMAN \& MOORE, supra note 13, at 118. See also Alan Sanfey et al., The Neural Basis of Economic Decision-Making in the Ultimatum Game, 300 SCIENCE 1755, 1755-58 (2003) (suggesting that the brain responds differently to unfair offers from humans and computers. In fact, after receiving an unfair offer from another person, the patterns in brain activation
} 


\section{Rationality, Expected Utility, and Prospect Theory ${ }^{21}$}

The conception of the homo economicus has also been reviewed on the element of rationality. The first major critique was made in 1955 by Herbert Simon's widely discussed article on "bounded rationality." 22 Accordingly, the rationality of human decisions at risk is limited because humans cannot calculate probabilities for any potential event that may or may not happen. ${ }^{23}$ More broadly speaking, they are not able to access all of the relevant information needed to make a decision. ${ }^{24}$ Human beings do not know all alternatives and potential outcomes and, hence, cannot accurately calculate the likelihood and value of such outcomes actually happening. ${ }^{25}$ For this reason, Simon concludes that humans choose the first option that satisfies them and which they recognize as such. ${ }^{26}$ This so-called process of satisficing is contrary to the concept of the homo economicus, which would argue that one always chooses the optimal alternative, thereby optimizing. ${ }^{27}$ Although Simon was able to show that human cognitive abilities are not infinite and therefore boundedly rational, he did not describe how boundedly rational people actually make their decisions.

In 1979, Amos Tversky and Daniel Kahneman introduced prospect theory, arguably the greatest influence of psychology on the field of economics. ${ }^{28}$ Kahneman $^{29}$ and Tversky took on the theory of decision-making under uncertainty that can be traced back as far as to Daniel Bernoulli in 1738. Bernoulli showed that the same dollar may be valued differently. That is to say, the utility depends on the current wealth of the person making the decision. ${ }^{30}$ In fact, a wealthier person will find lesser value or utility in an economically beneficial outcome than people in poverty. As Thaler puts it, "to a peasant, a \$100,000 windfall would be life-changing. To Bill Gates, it would go undetected." 31 The following graph illustrates the widely accepted concept of the diminishing marginal utility of wealth - in other words - the fact that utility does not increase linearly with an increase in wealth (see Figure 1):

Additionally — and more importantly for the purposes of this Article — the graph is able to explain risk aversion. For example, if one had the option to choose between a certain gain of $\$ 1,000$ or to get

changed considerably while an unfair offer from a computer merely led to slight changes); Sarah F. Brosnan \& Frans B. M. de Waal, Monkeys Reject Unequal Pay, 425 NATURE 297, 297-99 (2003) (offering a further compelling demonstration of crossspecies generality in fairness judgments. In their studies, capuchin monkeys refuse to accept cucumber if another capuchin monkey receives tasteful grapes for performing the same task).

${ }^{21}$ Prospect theory was originally named "lottery theory" because it was based on experiments involving people's behavior while playing the lottery.

${ }^{22}$ See Herbert A. Simon, A Behavioral Model of Rational Choice, 69 Q. J. EcON. 99, 99-188 (1955). In 1978, Simon received the Nobel Prize in Economics "for his pioneering research into the decision-making process within economic organizations."

${ }^{23}$ See Herbert A. Simon, Bounded Rationality, in The New Palgrave: A Dictionary of ECONOMICS 266, 266-67 (John Eatwell et al. eds., 1987).

${ }^{24}$ See generally Dolly Chugh \& Max Bazerman, Bounded Awareness: What You Fail to See Can Hurt You, 6 Mind \& Soc’y 4 (2007) (providing an explanation for why people cannot access all information necessary to make a fully-informed decision was given by the concept of "bounded awareness").

${ }^{25}$ See Simon, supra note 23, at 266.

${ }^{26}$ See generally Herbert A. Simon, Rational Choice and the Structure of the Environment, 63 PsYCHOL. REV. 129 (1956).

${ }^{27}$ See id. at 136.

${ }^{28}$ See Daniel Kahneman \& Amos Tversky, Prospect Theory: An Analysis of Decision Under Risk, 47 EcONOMETRICA, 263, 263-91 (1979) (initially introducing the prospect theory). See also Daniel Kahneman \& Amos Tversky, Values, Choices and Frames, 39 Am. Psychologist 341 (1984) (further developing the theory). See also Daniel Kahneman \& Amos Tversky, The Psychology of Preferences, 246 SCI. Am. 160, 160-73 (1982); Daniel Kahneman \& Amos Tversky, Advances in Prospect Theory: Cumulative Representation of Uncertainty, 5 J. Risk \& UnCERTAINTY 297, 297-323 (1992); Daniel Kahneman \& Amos Tversky, The Framing of Decisions and the Psychology of Choice, 211 SCIENCE 453, 453-58 (1982); Chris Guthrie, Prospect Theory, Risk Preference and the Law, 97 Nw. U. L. REv. 1115, 1115-64 (2003) (providing an overview including an analysis of the impact of prospect theory on legal studies).

${ }^{29}$ In 2002, Kahneman received the Nobel Prize in Economics "for having integrated insights from psychological research into economic science, especially concerning human judgment and decision-making under uncertainty."

${ }^{30}$ See Daniel Bernoulli, Exposition of a New Theory on the Measurement of Risk, 22 ECONOMETRICA 23, 23-36 (Louise Sommer trans., 1954).

${ }^{31}$ Richard H. Thaler, Misbehaving-The Making of Behavioral Economics 28 (2015). 


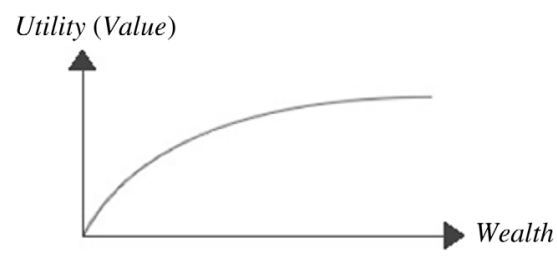

Figure 1. Diminishing Marginal Utility of Wealth.

a $50 \%$ chance of gaining $\$ 2,000$, one would always prefer the first option because the first $\$ 1,000$ is valued higher than the second $\$ 1,000$ due to diminishing marginal utility of wealth. ${ }^{32}$

The theory of how to make decisions under uncertainty as introduced by Bernoulli was further developed by Neumann and Morgenstern and finally named expected utility theory. ${ }^{33}$ To calculate the expected utility ( $\left.\mathrm{U}_{\text {Expected }}\right)$, one needs to multiply the probability of a potential event $\left(\mathrm{p}_{1}\right)$ happening with the utility of this event occuring $\left(\mathrm{U}_{1}\right)$ and add the result from multiplying the probability of another potential outcome happening $\left(\mathrm{p}_{2}\right)$ with the associated utility $\left(\mathrm{U}_{2}\right)$. In case there are only two alternative outcomes, $\mathrm{p}_{2}$ equals $1-\mathrm{p}_{1}$.

$$
\mathrm{U}_{\text {Expected }}=\mathrm{p}_{1} \cdot \mathrm{U}_{1}+\mathrm{p}_{2} \cdot \mathrm{U}_{2}\left(+\mathrm{p}_{3} \cdot \mathrm{U}_{3} \ldots\right)^{34}
$$

But, Kahneman and Tversky showed that expected utility theory partially contradicts people's choices in reality. Instead of focusing on how people would make their decisions from the classical economic perspective, they set out to describe the actual choices people make. ${ }^{35}$ Although prospect theory assumes that people try to maximize their utility, it also analyzes how-and to what extentpeople's decisions deviate in systematic and predictable manners. After all, it is a descriptive theory.

In particular, experiments show that choices made by participants depend on how the available options are framed. The fact that people may make different decisions over the same choice depending on the framing is illustrated by the widely discussed "Asian-Disease-Problem." 36 In this experiment, Kahneman and Tversky asked participants to choose between two alternative treatments to combat an Asian disease, which is expected to kill 600 people.

I. If program $\mathrm{A}$ is adopted, 200 people will be saved.

II. If program $B$ is adopted, there is a $2 / 3$ probability that no people will be saved and a $1 / 3$ probability that 600 people will be saved.

Accordingly, $72 \%$ of participants chose program A, to rescue 200 people for sure. Only $28 \%$ of the participants chose program $\mathrm{B}^{37}$ Such risk-avoiding behavior was not a big surprise, for Bernoulli's discoveries in 1738 pointed toward that direction as well. Then, Kahneman and Tversky reformulated the outcomes of the potential treatments in the following way:

I. If program $\mathrm{A}$ is adopted, 400 people will die.

II. If program $B$ is adopted, there is a $1 / 3$ probability that nobody will die and a $2 / 3$ probability that 600 people will die.

\footnotetext{
${ }^{32}$ See id. at 28.

${ }^{33}$ See generally Peter C. Fishburn, The foundations of EXPeCted Utility (1982) (providing a detailed analysis of expected utility theory).

${ }^{34}$ See infra Section B. III, where I come back to this equation when discussing how humans perceive probabilities.

${ }^{35}$ See THALER, supra note 31, at 29 (classifying prospect theory as a "theory about the behaviour of humans").

${ }^{36}$ See Daniel Kahneman \& Amos Tversky, The Framing of Decisions and the Psychology of Choice, 211 SCI. 453, 453-58 (1981). See also Anton Kühberger, et al., The Effects of Framing, Reflection, Probability, and Payoff on Risk Preference in Choice Tasks, 78 Org. Behav. \& Hum. Decision Processes 204, 204-31 (1999) (providing a meta-analysis of the Asiandisease-problem).

${ }^{37}$ See Kahneman \& Tversky, supra note 36, at 453.
} 
Figure 2. Value Function. The Utility of Losing and Finding $\$ 100$ bills.

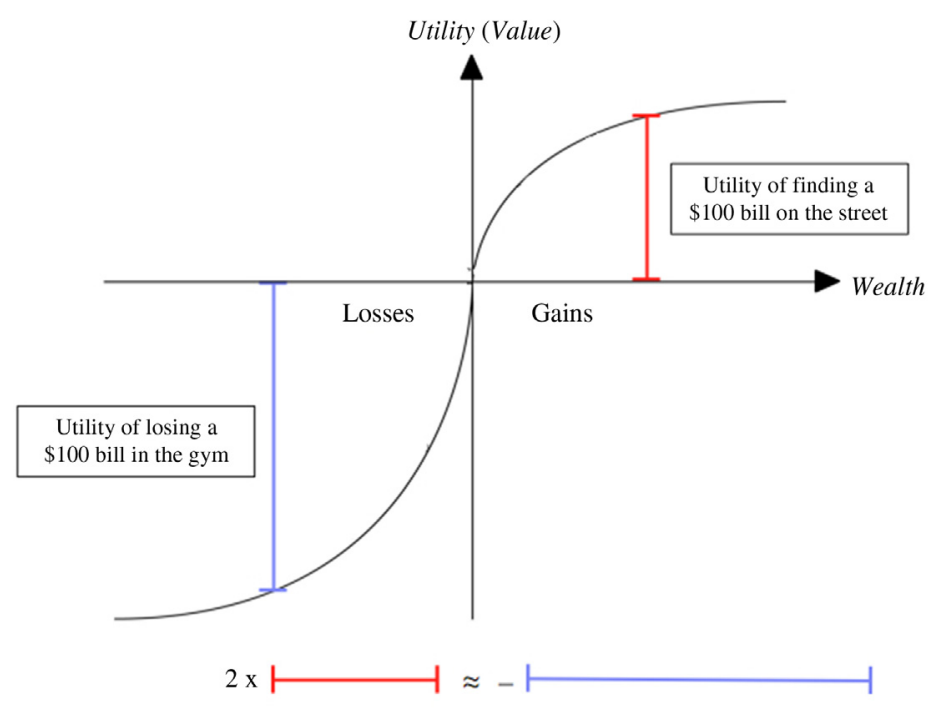

In this scenario, only $22 \%$ of the participants chose program A, while $78 \%$ chose program B. ${ }^{38}$ Despite the outcomes of program A and B remaining exactly the same, participants chose differently. Although the decision of the vast majority of people in the first scenario could be described as risk averse, participants in the second scenario chose the riskier option. Because of this, Kahneman and Tversky concluded that when looking at gains, people are risk averse, whereas people are risk seeking when facing losses. ${ }^{39}$ Consequently, people's risk attitudes and decisions depend on how the available options are framed. This so-called framing effect ${ }^{40}$ is a crucial part of prospect theory, yet there are many more systematic heuristics and biases.

Another central element of prospect theory is the concept of loss aversion. ${ }^{41}$ Loss aversion describes the tendency to prefer avoiding losses to acquiring gains. Simply put, people hate losing more than they like winning which is contrary to what expected utility theory suggests. The value of gains and equivalent losses is illustrated by Figure $2^{42}$ below. For instance, people would hate to lose a $\$ 100$ bill more than they would be happy about finding one. To be more precise, humans seem to hate losing about twice as much as they like winning. ${ }^{43}$

One example of loss aversion is the endowment effect. In a famous study at Cornell University, half of the participants were given a Cornell coffee mug while the other half did not get anything. ${ }^{44}$ Any rational choice theory would suggest that the price that the owner of the mug wants to receive

\footnotetext{
${ }^{38}$ See id.

${ }^{39}$ See id. Another classic example for the different risk attitudes can be observed in poker games. While players who are in a winning position act risk-averse, players who are about to lose tend to be risk-seeking.

${ }^{40}$ See generally Jeffrey Rachlinski \& Forest Jourden, Gains, Losses and the Psychology of Litigation, 70 S. CAL. L. REV. 121 (1996) (providing a detailed analysis of the framing effect).

${ }^{41}$ See ThaleR, supra note 31, at 34 (describing the concept of loss aversion as "the single most powerful tool in the behavioral economist's arsenal").

${ }^{42} \mathrm{Graph}$ designed by the author based on findings of Daniel Kahneman et al., Anomalies: The Endowment Effect, Loss Aversion, and Status Quo Bias, 5 J. ECON. Persp. 197 (1991).

${ }^{43}$ See Guthrie, supra note 28, at 1119.

${ }^{44}$ See Kahneman et al., supra note 42, at 197.
} 
for selling the mug is on average the same as the price that the participants who did not get a mug in the first place are willing to pay. But the experiment showed that owners requested roughly twice as much —on average about $\$ 5.25$ - than potential buyers were willing to pay-on average about $\$ 2.50 .{ }^{45}$ A similar study conducted by Krueger found that fans who were able to buy a ticket for the Super Bowl for $\$ 400$ or less would not have been willing to pay $\$ 3,000$, but they were also not willing to sell the ticket for $\$ 3,000 .{ }^{46}$ Many related studies followed, confirming that owners value a good about twice as much as potential buyers, thereby determining the intensity of the endowment effect. ${ }^{47}$

The result of such studies can be explained by the immediate effects of the broader principles behind loss aversion. While mug owners consider selling the mug as losing, buyers consider the transaction as gaining a mug. The reason why humans weigh losses twice as much as they weigh gains remains highly uncertain and widely discussed. Though, it should be noted that this work concentrates on the value of taking into account the effects when making judicial decisions, rather than discussing potential evolutionary psychological reasons, which may be able to explain such effects. ${ }^{48}$

Despite the fact that there are different approaches to the notion of rationality, understanding this concept requires at the very least coherency among an individual's choices. Because the decisions and preferences partially contradict each other, real-life human decision-making cannot be qualified as rational from the vast majority of perspectives on rationality and clearly not from the point of view of the traditional rational choice model. Crucially, this is so, regardless of whether the use of heuristics itself is rational. There may even be good evolutionary explanations for using fast and intuitive thought processes over slow and deliberative thinking. But, while the metadecision to use more effective thought processes most of the time may be rational, the fact that more specific decisions deviate from those, that the concept of the homo economicus would predict, is sufficient to question the rationality of such decisions.

\section{The Impact and Relevance of Behavioral Economics}

Although prospect theory is a descriptive theory — which is usually less accepted by economists—its implications have been wide and intense. ${ }^{49}$ Behavioral decision theory, as the field was primarily called in the 1980s and 1990s, led to many experiments being conducted by leading economic scholars such as George Akerlof, ${ }^{50}$ Colin Camerer, ${ }^{51}$ Matthew Rabin, ${ }^{52}$ Reinhard Selten, ${ }^{53}$ and

\footnotetext{
${ }^{45}$ See Kahneman et al., supra note 42, at 197.

${ }^{46}$ See Alan B. Krueger, Supply and Demand: An Economist Goes to the Super Bowl, 3 MilKen Inst. Rev. 22, 22-29 (2001).

${ }^{47}$ See John K. Horowitz \& Kenneth E. McConnell, A Review of WTA/WTP Studies, 44 J. EnvTL. Econ. \& MGMT. 426, 426-47 (2002) (involving studies with, inter alia, chocolate bars, pencils, theater tickets, radioactive waste disposal sites, and potentially poisonous sandwiches).

${ }^{48}$ See Elizabeth Hoffman \& Matthew L. Spitzer, Willingness to Pay vs. Willingness to Accept: Legal and Economic Implications, 71 WASH. U.L.Q. 59, 89-114 (1993) (showing that the most common explanation seems to be that organisms that treat threats as more urgent than opportunities have a greater chance to survive). See also Owen D. Jones, Time-Shifted Rationality and the Law of Law's Leverage: Behavioral Economics Meets Behavioral Biology, 95 Nw. U.L. REV. 1141, 1141-205 (2001).

${ }^{49}$ See generally Richard H. Thaler, From Homo Economicus to Homo Sapiens, 14 J. ECON. PersP. 138 (2000).

${ }^{50}$ See George Akerlof, Procrastination and Obedience, 81 AM. Econ. REV. 1, 1-19 (1991).

${ }^{51}$ See generally Colin CAMerer, Behavioral Game Theory: Experiments in STRATegic Interaction (2003).

${ }^{52}$ See Matthew Rabin, Incorporating Fairness into Game Theory and Economics, 83 AM. EcON. REv. 1281, 1281-302 (1993). See also Matthew Rabin, Psychology and Economics, 36 J. ECON. LITERATURE 1, 11-46 (1996).

${ }^{53}$ See generally Gerd Gigerenzer \& Reinhard Selten, Rethinking Rationality, in Bounded Rationality: The AdAPTIVE Toolbox 1 (Gerd Gigerenzer \& Reinhard Selten eds., 2001).
} 
Richard Thaler. ${ }^{54}$ Financial theorists were among the first to reexamine their models, for instance the efficient market hypothesis. ${ }^{55}$ In January 2015, the World Bank recognized that "organizations should implement procedures to mitigate [biases], and [this] may alter the entire field of development economics." 56 Numerous governments have installed specific teams whose work is based on applying the findings of behavioral economics, such as the Behavioral Insights Team in the UK and Peru or the Nudge Units in, among others, the US, Australia, Germany, and Singapore.

Since the 1990s, the influence of behavioral economics on law is on the rise. Research-mostly conducted in the US - tries to implement the relevant findings towards different legal issues. The field - which is often referred to as behavioral law and economics - has been gaining more attention since the publication of Sunstein, Jolls and Thaler's "A Behavioral Approach to Law and Economics." ${ }^{27}$ This article became the most cited source in legal studies since $1991^{58}$ and the number of contributions in the field, mainly in the US, ${ }^{59}$ has been rising ever since. Vast areas including European Union law, however, remain widely untouched. ${ }^{60}$

It is crucial to note that biases and heuristics apply to all humans involved in a decision-making process. With regards to financial markets, an investor may analyze how she forms a choice herself. At the same time, it also may be relevant to explore how other participants in the relevant market act and how this may influence one's own decision. As for judgments by the European courts, there are two potential dimensions in which an investigation into the importance of taking behavioral economics into account seems promising.

First, behavioral economics is able to predict reactions of the addressee of the judgment-at least to a certain extent and perhaps better than any rational choice model could do. ${ }^{61}$ Because EU law is - to a great extent-based on case law, the judgment of the European Court of Justice ("ECJ" or the "Court") arguably implies a legislative character. ${ }^{62}$ From this perspective, the evaluation of cognitive illusions may be particularly useful with regard to any consumer related law. ${ }^{63}$ As interesting as this first dimension may sound, this Article will focus on a second dimension:

\footnotetext{
${ }^{54}$ See generally Richard H. Thaler, Quasi-Rational Economics (1994). See also Richard H. Thaler, Doing Economics without Homo Economicus, in Foundations of ResEARCH IN ECONOMICS 115-34 (Steven Medema \& Warren Samuels eds. 1996).

${ }^{55}$ See Robert Shiller, Irrational Exuberance 171-90 (2000) (stating that the efficient market hypothesis-in its strict form-implies that any share of any company reflects its intrinsic value, for its relation to the homo economicus). See also Richard A. Brealey et al., Principles of Corporate Finance 352-86 (2013) (providing an overview).

${ }^{56}$ World BANK, World Development Report: Mind Society \& BeHAVior 18 (2015), http://www.worldbank.org/ content/dam/Worldbank/Publications/WDR/WDR\%202015/WDR-2015-Full-Report.pdf. See also Russel Korobkin, What Comes after Victory for Behavioral Law and Economics, 5 U. ILL. L. REV. 1655 (2011) (stating that "the battle to separate the economic analysis of legal rules and institutions from the straightjacket of strict rational choice assumptions has been won"); THALER, supra note 31, at 269 (providing a view that is a bit more suspicious and does not go beyond "mission launched").

${ }^{57}$ See Cass R. Sunstein et al., A Behavioral Approach to Law and Economics, 50 STAN. L. ReV. 1471, 1471-550 (1998)

${ }^{58}$ See Fred R. Shapiro \& Michelle Pearse, The Most-Cited Law Review Articles of All Time, 110 MiCH. L. REV. 1483, 1483-520 (2012).

${ }^{59}$ Compare with Philipp Hacker, The Behavioral Divide: A Critique of the Differential Implementation of Behavioral Law and Economics in the US and the EU, 11 EUR. REV. CONT. L. 299, 299-345 (2015).

${ }^{60}$ Consumer-related laws may be viewed as an exception to the rule. The most thorough contribution so far has arguably been made by Klaus Mathis et al., European Perspectives on Behavioural Law and Economics (2015). See also Alberto Alemanno \& Anne-Lise Sibony eds., Nudge and the Law-A European Perspective (2015).

${ }^{61}$ See generally Christine Jolls \& Cass Sunstein, Debiasing through Law, 35 J. LEGAL STUD. 233 (2006); Anne-Lise Sibony \& Alberto Alemanno, The Emergence of Behavioral Policy-Making: A European Perspective, in NUDGE AND THE LAW - A European Perspective 11 (Alberto Alemanno \& Anne-Lise Sibony eds., 2015) (providing a more European note); Eyal Zamir, Law, Psychology and Morality: The Role of Loss Aversion (2015) (providing a deep analysis on the normative implications of the loss aversion of consumers).

${ }^{62}$ See Catherine Barnard, The Substantive Law of the EU 377 (2013).

${ }^{63}$ See generally Richard H. Thaler \& Cass Sunstein, Nudge: Improving Decisions about Health, Wealth, and Happiness (2008). See also Marc White, The Manipulation of Choice - Ethics and Libertarian Paternalism 61-127 (2013) (regarding its critical voices pertaining to an increase of paternalism).
} 
The impact of cognitive illusions on judicial decision-making within the European Union courts. Instead of concentrating on decisions and preferences of the addressees of the judgment, systematic biases of the judges themselves are the point of focus.

\section{Critique of Behavioral Economics}

So far, it has been shown that heuristics such as the anchoring effect may play a significant role when making everyday decisions. But do heuristics and biases really occur when making important decisions? And do they still occur when experienced judges or experts make their decisions?

The argument that biases do not apply to experts-whether economists, sociologists, or lawyers-is one of the major critiques of behavioral economics. Yet, many studies show that experts, including judges, are just as likely to rely on irrelevant factors as any other person. ${ }^{64}$ For instance, Englich and Mussweiler asked German judges with courtroom experience of, on average, 15 years to give a judgment on a specific criminal law case. ${ }^{65}$ If the prosecutor pleaded for a sentence of 34 months' imprisonment, judges on average decided to give a sentence of slightly more than 35 months. ${ }^{66}$ Yet, if the prosecutor pleaded for 12 months' imprisonment, judges on average decided to hand down a sentence of 28 months. ${ }^{67}$

On the one hand, one may criticize such studies by outlining that biases do not appear when facing very important decisions such as real-life judgments by the European courts. In contrast to the many studies that have been conducted, when it comes to actual influential decisions to make, judges may be more motivated to give an accurate judgment. Additionally, one might argue that they have more time and resources to devote to the decision. ${ }^{68}$ On the other hand, regardless of whether judges are able to obtain better background information or in-depth facts before making a decision, information and time will always be limited. ${ }^{69}$ It has even been argued that more detailed information may lead to more powerful illusions. ${ }^{70}$ It shall further be noted that if judges are unaware of the potential cognitive shortcuts, "extra time and resources will be of no help."71 Lastly, Kachelmeier and Shehata demonstrate that systematic errors such as the framing effect may still remain even if the outcome involves a two-month salary-showing that the decision was indeed a very important one. ${ }^{72}$

The fact that experts are also biased can be explained by examining how the brain makes decisions more generally. Referring to the highly influential dual-process theory, Kahneman points out that there are two types of thinking. ${ }^{73}$ While system 1 thinking may be described as fast, automatic, frequent, emotional, stereotypic, and subconscious, system 2 thinking is considered to be slow,

\footnotetext{
${ }^{64}$ See William Meadow \& Cass Sunstein, Statistics, Not Experts, 51 Duke L.J. 629-46 (2001). See generally Daniel Kahneman \& Amos Tversky, Extensional Versus Intuitive Reasoning: The Conjunction Fallacy in Probability Judgment, 90 PsYCHOL. REV. 308 (1983). See also William J. Qualls \& Christopher P. Puto, Organizational Climate and Decision Framing: An Integrated Approach to Analyzing Industrial Buying Decisions, 26 J. MKTG. Res. 179-92 (1989); Michael J. Roszkowski \& Glen E. Snelbecker, Effects of "Framing" on Measures of Risk Tolerance: Financial Planners Are Not Immune, 19 J. BEHAV. ECON. 237-46 (1990). For further sources, compare the comprehensive list including military leaders, engineers, accountants, doctors, real estate appraisers, option traders, psychologists, and lawyers presented in Guthrie et al., supra note 4 , at 783.

${ }^{65}$ See Birte Englich \& Thomas Mussweiler, Anchoring Effects in the Courtroom, 31 J. ApPLIED SOC. PsYCHOL. 1535, 1535-551 (2001).

${ }^{66} \mathrm{See}$ id. at 1535.

${ }^{67}$ See id. at 1536.

${ }^{68}$ See Guthrie et al., supra note 4 , at 819.

${ }^{69}$ See Guthrie et al., supra note 4 , at 820 .

${ }^{70}$ See Jeffrey J. Rachlinski, A Positive Psychological Theory of Judging in Hindsight, 65 U. CHI. L. REv. 571, 576 (1998).

${ }^{71}$ Guthrie et al., supra note 4, at 820 .

${ }^{72}$ See Kachelmeier \& Shehata, supra note 17, at 1123. See also Guthrie et al., supra note 4, at 820 (considering this argument as "the best support for the conclusion that susceptibility to cognitive illusions will persist in the face of high motivation and great detail”).

${ }^{73}$ See Daniel Kahneman \& Shane Frederick, Representativeness Revisited: Attribute Substitution in Intuitive Judgment, in Heuristics And Biases: The Psychology of Intuitive Judgment 49-81 (Thomas Gilovich et al. eds., 2002).
} 
effortful, infrequent, logical, calculating, and conscious. ${ }^{74}$ The great majority-approximately $95 \%$ of all decisions individuals make-is merely based on system 1 thinking. ${ }^{75}$ It is not only fast, but the decisions are also mostly correct in terms of maximizing expected value, making it a very efficient type of thinking. Case in point, a soccer player does not thoroughly analyze whether it may be better to pass the ball to the right or the left wing. She just does it. An employee does not reconsider everyday whether it may be better to take the bike or the train to go to work. She just takes the one she always uses, even though parameters such as the weather or the train schedule may have changed. And given the efficiency of system 1 thinking, it may itself be rational to rely mostly on system 1 thinking.

But, even if most of the decisions made by system 1 are correct and one can easily see that humans without the related thought processes will have significant problems in everyday life, the system will be mistaken at times. For example, in the previously introduced study by Englich and Mussweiler, German judges decided differently depending on the plead of the prosecutor thereby laboring under the anchoring effect. As it was already argued and empirically supported by Konecni and Ebbesen, judicial decisions are - to a great extent-based on system 1 thinking. ${ }^{76}$ Even though judges are experienced, well-trained, and highly motivated decision-makers, they are vulnerable to cognitive illusions. ${ }^{77}$ And for this reason, it is important to find methods to mitigate cognitive biases. ${ }^{78}$

Another major criticism focuses on the theoretical basis of behavioral economics. Because there is no fundamental underlying theory, behavioral economics is not able to predict human behavior as well as rational choice theory. ${ }^{79}$ In particular, Gigerenzer criticizes that behavioral economics achieves little more than describing certain phenomena, which are rather vague and not clearly defined. ${ }^{80}$ There is no question that a clear and full-fledged theory of how humans actually make decisions would be a, or even the, great discovery. Nevertheless, it may still be beneficial to implement the findings of behavioral economics. In order to mitigate biases, knowing what biases could occur may be even more important than knowing why they occur, especially in relation to judicial decision-making. ${ }^{81}$ Although a theory is, of course, preferable, behavioral economics at this stage may be better understood and used as a very pragmatic tool to improve judicial decision-making. ${ }^{82}$ From this perspective, the lack of a consistent theory does not have major consequences for behavioral law and economics in general or for this Article in particular. ${ }^{83}$

\footnotetext{
${ }^{74}$ See id. at 51 (using the terminology of "system 1" and "system 2" thinking as originally introduced by Keith E. Stanovich \& Richard F. West, Individual Differences in Reasoning: Implications for the Rationality Debate, 23 BEHAV. \& BRAIN SCI. 645, 658 (2000)). See generally Joshua Greene, Moral Tribes (2014) (using the different modes of a digital DSLR camera); JonAtHAN Haidt, The Righteous Mind: Why Good People Are Divided by Politics and Religion (2013) (preferring to think about the different thought processes as rider (system 2) and elephant (system 1)).

${ }^{75}$ See Kahneman \& Frederick, supra note 73, at 55.

${ }^{76}$ See generally Vladimir J. Konecni \& Ebbe B. Ebbesen, The Mythology of Legal Decision Making, 7 INT'L J.L. \& PsYCHIATRY 5 (1984). See also van Petrus Duyne, Simple Decision Making, in The Psychology of Sentencing 151 (Donald C. Pennington \& Sally Lloyd-Bostock eds., 1987); Mandeep K. Dhami \& Peter Ayton, Bailing and Jailing the Fast and Frugal Way, 14 J. Behav. Decision MaKing 161 (2001).

${ }^{77}$ See Guthrie et al., supra note 4, at 778. See also MORRIS R. COHEN, LAW AND THE SOCIAL ORdER: EsSAYS IN LEGAL Philosophy 337 (1933) (putting it simply by stating that "we must not forget that actual law is a human product - made and administered by judges who are not free from human limitations in intelligence and goodwill”).

${ }^{78}$ Also referred to as "debiasing."

${ }^{79}$ See generally Gerd Gigerenzer, How to Make Cognitive Illusions Disappear: Beyond "Heuristics and Biases," 2 EUR. REv. Soc. Psychol. 101 (1991). See also Gerd Gigerenzer, On Narrow Norms and Vague Heuristics: A Rebuttal to Kahneman and Tversky, 103 PsychOL. REv. 592, 592-96 (1996).

${ }^{80}$ See Gigerenzer, supra note 79 , at 104.

${ }^{81}$ See Mark Schweizer, Kognitive Täuschungen vor Gericht 32 (2005).

${ }^{82}$ See generally Russel Korobkin \& Thomas S. Ulen, Law and Behavioral Science: Removing the Rationality Assumption from Law and Economics, 88 CAL. L. Rev. 1075 (2000). See also GebHard KirCHgÄssner, Homo Oeconomicus 258 (4th ed. 2013).

${ }^{83} \mathrm{See}$ Thomas Kuhn, The Structure of Scientific Revolutions 52 (1970). On a more general note, it can be mentioned that a profound theory is desirable, however, as Kuhn notes, "discovery begins with the awareness of anomaly."
} 


\section{Summary}

So far, it has been argued that the concept of the homo economicus does not accurately describe how humans behave in the real world. In particular, it was highlighted that two crucial elementsnamely the self-interested and rational character of human decision-making-cannot be upheld given the findings of behavioral economists and cognitive psychologists. The research conducted by Tversky and Kahneman particularly points out that various cognitive illusions apply when making decisions under uncertainty. Although rules of thumb may lead to easier and faster decision-making and can ultimately be very efficient, they may also cause systematic errors. The efficiency of system 1 thinking makes it a great tool for everyday decisions, but when it comes to judgments of the European courts, it may be worthwhile to engage in system 2 thinking. As it is currently not feasible to switch deliberatively between different thought processes, it may be most beneficial to try to eliminate-or at least mitigate - the effect of cognitive biases. For this reason, the following analysis will come back to some of the abovementioned biases, their application in selected substantive and procedural legal issues, and will make concrete policy suggestions.

\section{Applying Cognitive Illusions to EU Judicial Decision-Making}

The third part of this Article is going to focus on the application of specific biases in the context of EU law with a special emphasis on the fundamental freedoms of the internal market. Given the fact that prospect theory is a descriptive theory, it seems advantageous to introduce selected biases by giving examples from recent studies. Hereafter, the relevancy of accounting for the specific cognitive illusion in the process of judicial decision-making regarding EU law will be examined. At the final stage of each analysis, potential solutions to overcome the bias will be discussed. The primary focus will lie on the anchoring effect (I.), availability bias (II.), zero-risk bias (III.), and hindsight bias (IV.).

\section{Anchoring Effect}

\section{Introduction}

Anchoring is a cognitive bias that describes the tendency of individuals to rely too heavily on the first piece of information offered-the "anchor" - when making decisions. ${ }^{84}$ Once an anchor is set, the consequent decisions are made by adjusting away from that anchor. ${ }^{85}$ But, people adjust insufficiently. ${ }^{86}$ Even more problematic seems that anchors that do not provide any useful information may still influence the judgment. This concept applies even if the decision-maker knows that the initial information does not add any value to the decision-making process. ${ }^{87}$

In one study, Tversky and Kahneman asked participants to spin a wheel of fortune. ${ }^{88}$ The wheel was rigged to stop at either ten or at sixty-five. ${ }^{89}$ After spinning the wheel, participants had to estimate the percentage of African countries in the United Nations. ${ }^{90}$ When the wheel landed on ten, participants on average estimated that $25 \%$ of African countries are members of the United Nations. ${ }^{91}$ Yet, when the wheel landed on sixty-five, participants estimated that $45 \%$ of African countries are in the United Nations. ${ }^{92}$ Even payoffs for accuracy did not change the

\footnotetext{
${ }^{84}$ See generally Amos Tversky \& Daniel Kahneman, Judgment under Uncertainty: Heuristics and Biases, 185 SCIENCE 1128 (1974).

${ }^{85}$ Therefore, anchoring has also been referred to as "adjustment effect" or "focalism."

${ }^{86}$ See Tversky \& Kahneman, supra note 84 , at 1128.

${ }^{87}$ See Tversky \& Kahneman, supra note 84, at 1129. See also Guthrie et al., supra note 4, at 788.

${ }^{88}$ See Tversky \& Kahneman, supra note 84 , at 1128.

${ }^{89}$ See Tversky \& Kahneman, supra note 84 , at 1128.

${ }^{90}$ See Tversky \& Kahneman, supra note 84 , at 1128.

${ }^{91}$ See Tversky \& Kahneman, supra note 84, at 1128.

${ }^{92}$ See Tversky \& Kahneman, supra note 84 , at 1128.
} 
result. ${ }^{93}$ In another study, participants_-Group One-were asked whether Mahatma Gandhi died before or after the age of nine. ${ }^{44}$ Other participants_-Group Two-were asked whether he died before or after the age of $140 .{ }^{95}$ Thereafter, both groups were asked at what age Gandhi died. ${ }^{96}$ While Group One estimated that Gandhi died at the age of 50, Group Two estimated that Gandhi was 67 years old when he died. ${ }^{97}$ Despite the fact that it was clear to participants that Gandhi certainly died neither at the age of nine nor at the age of $140,{ }^{98}$ the estimates of Group One and Two differed significantly, ${ }^{99}$ hence, irrelevant information can have a great effect on the human process of decision-making. ${ }^{100}$

The most striking study with legal implications concerning the anchoring effect may be the previously introduced results by Englich and Mussweiler regarding the impact of the prosecutor's plea $^{101}$ or the rolling of dice before handing down a sentence. ${ }^{102}$

\section{Reporting Judge and Advocate General: Spotting Anchors within the Procedure}

As these examples show, the anchoring has a significant effect on people's decision-making process regardless of whether the anchor provides useful guidance or not. Because the effect applies to laypeople as well as to experts, there is no reason to assume that decisions of judges applying EU law are not affected. It is therefore crucial to consider where potential anchors are located and how to avoid them. Two of the potentially countless sources of anchors are rather obvious and play a significant role within judicial decision-making in EU law: The reporting judge and the Advocate General.

The most notable work of the Advocate General is to deliver a written opinion, the so-called reasoned submission, which is often referred to as the "starting point" for the deliberation of judges. ${ }^{103}$ Indeed, the influence of the Opinion of the Advocate General is significant, perhaps illustrated by the fact that most judgments follow the Opinion. ${ }^{104}$ For instance, the ECJ in Chen ${ }^{105}$ cited the Advocate General almost exactly. Still, one must bear in mind that simply following the Advocate General's proposal does not mean that those judges were biased. After all, it may well have been the correct way to solve the particular case.

Arguably, the reporting judge may even produce a more distinct anchor, as she is preparing the preliminary report ${ }^{106}$ for the General Meeting ("réunion générale"), thereby setting the first-and psychologically most influential-anchor in the whole proceeding. Furthermore, the judge rapporteur delivers the first draft of the judgment, while the Advocate General is still preparing her Opinion. In the preliminary report, the reporting judge will already address the central issues of the case. ${ }^{107}$

\footnotetext{
${ }^{93}$ See Tversky \& Kahneman, supra note 84, at 1128.

${ }^{94}$ See Fritz Strack \& Thomas, Mussweiler, Explaining the Enigmatic Anchoring Effect: Mechanisms of Selective Accessibility, 73 J. Personality \& Soc. Psychol. 437, 437-46 (1997).

${ }^{95}$ See id. at 440 .

${ }^{96}$ See id.

${ }^{97}$ See id.

${ }^{98}$ For those who wonder, Mahatma Gandhi died at the age of 78 .

${ }^{99}$ See Strack \& Mussweiler, supra note 94 , at 441.

${ }^{100}$ See Strack \& Mussweiler, supra note 94 , at 441.

${ }^{101}$ See supra Section B.IV.

${ }^{102}$ Englich et al., supra note 6. See also Jeffrey J. Rachlinski et al., Can Judges Make Reliable Numeric Judgments? Distorted Damages and Skewed Sentences, 90 IND. L.J. 695, 695-739 (2015).

${ }^{103}$ See generally David Edward, How the Court of Justice Works, 20 Eur. L. REv. 555 (1995).

${ }^{104}$ See id.

${ }^{105}$ See generally Case C-200/02, Zhu and Chen v. Sec'y of State for Home Dep't, 2004 E.C.R. I-09925.

${ }^{106}$ Article 44(2) of the Rules of Procedure defines what elements should be contained in the report.

${ }^{107}$ See generally Laure Clement-Wilz, The Advocate General: A Key Actor of the Court of Justice of the European Union, 14 CAmbridge Y.B. Eur. Legal StUd. 603 (2012).
} 
Thereafter, when solving the case, judges will often try to confirm what has already been suggested by the reporting judge, thereby suffering from the anchoring effect. ${ }^{108}$

To completely eliminate the bias, it would be better if every single judge would solve the case on her own before looking at any draft or suggestions. As Guthrie et al. argue, "it is much easier to avoid stepping on a patch of ice than it is to keep your footing once you have stepped on it." ${ }^{109}$ At the same time, the function of the reporting judge is to make the chambers more efficient due to the immense workload. ${ }^{110}$ Thus, an elimination of the cognitive bias in this way would go hand in hand with an elimination of the provided efficiency by this procedure. Yet, as Judge van der Woude points out, there may be a different, more efficient way to mitigate the bias. Instead of trying to confirm, judges should try to disprove what has been suggested and only if they are not able to do so, the suggestions made should be confirmed. ${ }^{111}$ In fact, the process of trying to disprove what has been suggested can lead to thinking about alternative solutions, which can be a mitigating factor to many biases, especially to the anchoring effect. ${ }^{112}$ This is particularly relevant for the anchoring effect because simply being aware of a potential anchor does not mitigate the effect. ${ }^{113}$

Moreover, the ability to imagine alternative outcomes is based on creativity, which is particularly strong among groups. ${ }^{114}$ In this regard, it shall be noted that more than $80 \%$ of cases for the European Court of Justice sit in in chambers of three or five judges. ${ }^{115}$ An increase in the number of judges in every case-rather than only the most important or controversial cases-would certainly improve creativity, thereby mitigating the anchoring effect. In light of limited financial means, however, it seems questionable-although theoretically desirable-whether this could be achieved in practice. ${ }^{116}$

To summarize, the anchoring effect is very difficult and costly to overcome. Yet, certain mental techniques-namely trying to think about alternative solutions-are able to limit the effect to a certain extent. Regarding this matter, judicial training in behavioral economics is necessary in order to mitigate the bias - a suggestion which will also be emphasized in the subsequent examination surrounding the availability bias.

\section{Availability Bias ${ }^{117}$}

\section{Introduction}

According to Tversky and Kahneman, "people assess the frequency of a class or the probability of an event by the ease with which instances or occurrences can be brought to mind." 118 The "most influential examination" so far has been carried out by Lichtenstein et al. in $1978 .{ }^{119}$ In their study,

\footnotetext{
${ }^{108}$ Interview with Marc van der Woude, Judge of the General Court of the European Union (Mar. 11, 2015).

${ }^{109}$ Guthrie et al., supra note 4 , at 828 .

${ }^{110}$ See generally CJEU, PRESS RELEASE NO. 27/15 13 (2015), https://curia.europa.eu/jcms/upload/docs/application/pdf/2015-03/ cp150027en.pdf. Compare also House of LORDs, WORKLOAD OF THE COURT OF JUSTICE OF THE EUROPEAN UNION: FOLLOW-UP REPORT 13 (2013), http://ec.europa.eu/dgs/secretariat_general/relations/relations_other/npo/docs/united_kingdom/own_initiative/ oi_workload_of_the_court_of_justice_follow_up_report/oi_workload_of_the_court_of_justice_follow_up_report_lords_opinion_ en.pdf.

${ }^{111}$ Interview with Marc van der Woude, Judge of the General Court of the European Union (Mar. 11, 2015).

${ }^{112}$ See Hal R. Arkes et al., Eliminating Hindsight Bias, 73 J. AppliEd Psychol. 305, 305-07 (1988).

${ }^{113}$ See Richard Block \& David Harper, Overconfidence in Estimation: Testing the Anchoring-and-Adjustment Hypothesis, 49 Org. Behav. \& Hum. Decision Processes 188, 188-207 (1991).

${ }^{114}$ See Norbert L. Kerr \& Scott Tindale, Group Performance and Decision Making, 55 AnN. Rev. PsyCHOL. 623, 623-55 (2004).

${ }^{115}$ See Damian Chalmers et al., European Union law: Cases and Materials 145 (2nd ed. 2010).

${ }^{116}$ I will come back to this issue when discussing the advantages of a de minimis rule, see infra Section C.III.2.

${ }^{117}$ Also referred to as "representativeness bias."

${ }^{118}$ Tversky \& Kahneman, supra note 84 , at 1127.

${ }^{119}$ See Daniel Kahneman, Thinking Fast and slow 138 (2011). See also Thorsten Pachur et al., How Do People Judge Risks: Availability Heuristic, Affect Heuristic, or Both?, 18 J. EXPERIMENTAL PsYCHOL. 314, 315 (2012).
} 
participants were asked to consider pairs of causes of death-for example "strokes" and "all accidents combined"-before participants were asked to indicate which one causes more people to die. ${ }^{120}$ Pertaining to the example already stated, $80 \%$ of respondents considered death by accident to be more likely than death by stroke. ${ }^{121}$ In reality, strokes cause about $85 \%$ more death than all accidents combined. ${ }^{122}$ Other examples showed that subjects considered death by accident and death by disease as equally likely, although death by disease is roughly 18 times more likely than death by accident. Tornadoes were seen as more likely to cause death than asthma, yet asthma is de facto 20 times more likely to cause death than tornadoes. ${ }^{123}$

Although participants sometimes correctly identified the cause of death that occurs more frequently, their ratios given were far too large. ${ }^{124}$ For instance, death by a motor cycle accident is indeed more likely than death by diabetes, however, participants assumed, on average, that it is 356 times more likely. In reality, motor cycle accidents are only 1.4 times more likely to cause death. ${ }^{125}$ Lichtenstein et al. showed that frequencies of dramatic events such as cancer, homicide, and tornadoes are overestimated, whereas the frequency of "quiet killers" is underestimated. ${ }^{126}$

The availability bias is closely related to the anchoring effect and, hence, similar problems arise when it comes to determining what the bias may cause. Nevertheless, there have been a tremendous amount of studies locating the source of the bias in different scenarios such as personal experience ${ }^{127}$ and media reports. ${ }^{128}$ For instance, unusual events_-such as shark attacks and airplane crashes_-are often reported disproportionately in mass media, and thus people overestimate the likelihood of such events occurring in the future. ${ }^{129}$

Research in behavioral law and economics so far has been mostly concerned with legislative bodies. This fact is relevant because cognitive biases are particularly strong when making decisions under uncertainty such as enacting new laws. Legislative bodies which usually enjoy a wide margin of discretion-for its members are often directly elected by the citizens - therefore need to conduct in-depth studies about the potential risks, effects, and unintended consequences of the law in question. At the same time, one must not forget that the judiciary often enjoys some discretion as well. Yet, while the issue of factual uncertainty remains providing a breeding ground for the availability bias, courts have been engaging much less with economic and statistical evidence concerning the effects of their judgment regarding the fundamental freedoms. ${ }^{130}$ This lack of engagement is particularly true for the European courts. The following analysis will therefore start by briefly outlining the margin of discretion that the EU judiciary enjoys regarding both the application and justification of the fundamental freedoms before moving on to suggest ways to mitigate the availability bias with a special focus on the proportionality test.

\footnotetext{
${ }^{120}$ See Sarah Lichtenstein et al., Judged Frequency of Lethal Events, 4 J. EXPERIMENTAL Psychol.: Hum. LEARNING \& MEMORY 551, 551-58 (1978).

${ }^{121}$ See id.

${ }^{122}$ See id.

${ }^{123}$ See id.

${ }^{124}$ See id.

${ }^{125}$ See id.

${ }^{126}$ See id. at 552. See also Guthrie et al., supra note 4, at 805 (providing specific studies examining the availability bias regarding judicial decision-making).

${ }^{127}$ See Melvin Manis et al., Availability Heuristic in Judgments of Set Size and Frequency of Occurrence, 65 J. PERSONALITY \& SOC. PSYCHOL. 448, 448-57 (1993) (providing an investigation of the impact of personal experience towards the availability bias by comparing people's ability to remember seeing a shark and/or a dolphin in the ocean).

${ }^{128}$ See Pablo Brinol et al., The Malleable Meaning of Subjective Ease, 17 PsYcHOL. SCI. 200, 200-06 (2006).

${ }^{129}$ See id. at 204. See also John D. Read, The Availability Heuristic in Person Identification: The Sometimes Misleading Consequences of Enhanced Contextual Information, 9 AppliEd COGNITIVE PsYCHOL. 91-121 (1995); Guthrie et al., supra note 4 , at 805 (providing further references).

${ }^{130}$ Oddly enough, this is different when it comes to competition law.
} 


\section{The Judiciaries' Margin of Discretion Regarding the Fundamental Freedoms}

Regarding EU internal market law, scope and restrictions of the fundamental freedoms have been interpreted extremely widely by the European Court of Justice. Pertaining to the free movement of goods pursuant to Article 34 TFEU, the infamous paragraph five of Dassonville states that "all trading rules enacted by Member States which are capable of hindering, directly or indirectly, actually or potentially, intra-Community trade are to be considered as measures having an effect equivalent to quantitative restrictions." ${ }^{31}$ Because the subsequent case law-in particular Keck \& Mithuard, ${ }^{132}$ Cassis de Dijon, ${ }^{133}$ Italy v. Commission (motorcycle trailers) ${ }^{134}$ and Mickelsson \& Roos (jet-skis) ${ }^{135}$ — missed out on establishing any clear boundaries, almost all measures enacted by a Member State somehow restrict the free movement of goods in terms of Article 34 TFEU. Similarly, Säger ${ }^{136}$ and Alpine Investment ${ }^{137}$ established a wide scope of the freedom to provide and receive services pursuant to Article 56 TFEU. With regard to the free movement of capital, the treaty itself, namely Article 63 TFEU, established a wide scope because it -in contrast to other freedoms-does not distinguish between discrimination-based and other restrictions. ${ }^{138}$

In the "give and take world of Cassis de Dijon," the wide application of the restrictions of the fundamental freedoms goes hand in hand with an equally wide scope of potential justifications. ${ }^{139}$ Arguably, there are three main reasons for this phenomenon. First, the non-exhaustive list of mandatory requirements ${ }^{140}$ has been extending ever since and covers wide areas such as "consumer protection,"141 "effectiveness of fiscal supervision," 142 the "protection of the environment," 143 "public health," more specific subjects such as the "protection of cinema as a form of cultural expression"146 or the "protection of books as cultural objects." 147

Second, some case law signals that the scope of the application of the already widely interpreted mandatory requirements is also extending. In particular, one is able to spot the tendency of the Court to apply mandatory requirements in cases of distinctly applicable measures. For instance, in Schindler, the Court justified a directly discriminatory measure by referring to consumer

\footnotetext{
${ }^{131}$ Case C-8/74, Procureur de Roi v. Dassonville, 1974 E.C.R. 837, para. 5.

${ }^{132}$ See generally Joined Cases C-267/91 \& C-268/91, Criminal proceedings against Bernard Keck and Daniel Mithouard, 1993 E.C.R. I-6097.

${ }^{133}$ See generally Case C-20/78, Rewe-Zentral AG v. Bundesmonopolverwaltung für Branntwein, 1979 E.C.R. 649.

${ }^{134}$ See generally Case C-110/05, Commission v. Italy, 2009 E.C.R. I-519.

${ }^{135}$ See generally Case C-142/05, Åklagaren v. Mickelsson \& Roos, 2009 E.C.R. 1-4271.

${ }^{136}$ See generally Case C-76/90, Säger v. Dennemeyer \& Co. Ltd., 1991 E.C.R. I-4221.

${ }^{137}$ See generally Case C-384/93, Alpine Investments v. Minister van Financiën, 1995 E.C.R. I-1141.

${ }^{138}$ See BARNARD, supra note 61 , at 231-43, 308-11 (providing an analysis of the scope of the free movement of workers pursuant to Article 45 TFEU and the freedom of establishment pursuant to Article 49 TFEU).

${ }^{139}$ Catherine Barnard, Derogations, Justifications and the Four Freedoms: Is State Interest Really Protected?, in THE OUTER Limits of European LAW 273 (Catherine Barnard \& Okeoghene Odudu eds., 2009).

${ }^{140}$ See Case C-279/80, Criminal Proceedings against Webb, 1981 E.C.R. 3305, paras. 16-17. Whereas the terminology "mandatory requirements" seems to prevail regarding Article 34 TFEU, the court also refers to "overriding reasons of public interests," "imperative requirements," "justified by the general good." See also Case C-224/97, Ciola v. Land Vorarlberg, 1999 E.C.R. I-2517, para. 15, where "mandatory grounds in the general interests." Although a different terminology suggests a different content, it seems that those descriptions are used synonymously. For the sake of simplicity, this Article will restrict itself to the expression "mandatory requirements."

${ }^{141}$ See Case C-120/78, Rewe-Zentral AG v. Bundesmonopolverwaltung für Branntwein, 1979 E.C.R. 649, para. 8.

${ }^{142}$ See Case C-823/79, Criminal Proceedings against Carciati, 1980 E.C.R. 2773, para. 9.

${ }^{143}$ See Case C-302/86, Commission of the European Communities v. Kingdom of Denmark, 1988 E.C.R. 4607, paras. 1-2.

${ }^{144}$ See Case C-788/79, Criminal proceedings against Herbert Gilli and Paul Andres, 1980 E.C.R. 2071, para. 6. Although covered in Article 36 TFEU, "public health" was dealt with as a mandatory requirement initially in this case.

${ }^{145}$ Case C-145/88, Torfaen Borough Council v. B\&Q plc, 1989 E.C.R. 3851, para. 11.

${ }^{146}$ Case C-60/84, Cinéthèque v. Fédération Nationale des Cinémas Français, 1985 E.C.R. 2605, paras. 16, 23.

${ }^{147}$ Case C-531/07, Fachverband der Buch- und Medienwirtschaft v. LIBRO Handelsgesellschaft mbh, 2009 E.C.R. I-3717, para. 34 .
} 
protection. ${ }^{148}$ In the area of environmental protection, the Court refused to acknowledge that-for historical reasons - ${ }^{149}$ environmental protection has not been listed as a justification within the treaty but now needs to be applied equally. Instead, in Preußen Elektra ${ }^{150}$ and more recently in Essent ${ }^{151}$ the Court circumvented the issue by simply applying "environmental protection" as a means of justifying restrictions to the market. It remains unclear whether mandatory requirements can still—as stated in Cassis de Dijon ${ }^{152}$ —be applied exclusively to indistinctly applicable measures or whether their scope has been broadened in general, or at least with regard to certain requirements, such as with the protection of the environment.

Third, the scope of fundamental rights has been broadened extensively due to a) their doublefunction as a "sword" and a "shield" 153 and b) the extensive interpretation of Article 51 of the Charter of Fundamental Rights in Franson. ${ }^{154}$ From the extensive application of mandatory requirements and fundamental rights, it follows that more cases will be decided by balancing different fundamental freedoms and fundamental rights within the proportionality test.

\section{Biased Balancing within the Proportionality Test}

Although the proportionality test was initially meant to be a four-stage test, ${ }^{155}$ in practice the test has become highly unstructured. The third and fourth stages of the test - namely whether the measure in question is "suitable for securing the attainment of the objective which the measure pursues" 156 and that it "must not go beyond what is necessary in order to attain it"157 —in several cases have been transformed to a single test of balancing. ${ }^{158}$ On the one hand, this kind of balancing necessarily implies a great degree of discretion thereby "placing judges at the outer limits of their legitimate judicial role, where the judiciary risks substituting its assessment for that of the legislature." 159 On the other hand, balancing among the different fundamental freedoms, fundamental rights, and general principles of EU law requires the European courts to assess on a caseby-case analysis which freedom or right prevails. ${ }^{160}$ Accordingly, the courts must determine to what extent a right has been restricted and to what extent it is necessary to protect a right by declaring measures which would impose unjustified restrictions on the right or freedom in question as incompatible with EU law. To name a classic example, the Court in Schmidberger had to examine whether Austrian authorities granting permission for a demonstration on the Brenner

\footnotetext{
${ }^{148}$ See Case C-275/92, H.M. Customs and Excise v. Schindler, 1994 E.C.R. I-1039, para. 54. See also Case C-205/07, Gysbrechts and Santurel-Inter, 2008 E.C.R. I-9947; Case C-524/07, Commission v. Austria, 2008 E.C.R. I-187.

${ }^{149}$ See Case C-275/92, H.M. Customs and Excise v. Schindler, 1994 E.C.R. I-1039, para. 86 (opinion of AG Bot).

${ }^{150}$ See Case C-379/98, Preußen Elektra v. Schleswag AG, 2001 E.C.R. I-2099, paras. 73, 82.

${ }^{151}$ See generally Joined Cases C-204/12 \& C-208/12, Essent Belgium NV v. Vlaamse Reguleringsinstantie voor de Elektriciteits- en Gasmarkt (Sept. 11, 2014).

${ }^{152}$ See Case C-120/78, Rewe-Zentral AG v. Bundesmonopolverwaltung für Branntwein, 1979 E.C.R. 649, para. 8.

${ }^{153}$ See EJC Case C-544/10, Deutsches Weintor eG v. Land Rheinland-Pfalz, ECLI:EU:C:2012:526, Judgment of 6 Sept. 2012 (providing an example of fundamental rights being used as both a "sword" and a "shield" in one case).

${ }^{154}$ See Case C-617/1, Åklagaren v. Hans Åkerberg Fransson, 2013 E.C.R. I-0000, para. 29. See also Case C-206/13 Siragusa v. Sicilia, 2014 E.C.R. I-126, para. 24.

${ }^{155}$ See Case C-55/94, Gebhard v. Consiglio dell'Ordine degli Avvocati e Procuratori di Milano, 1995 E.C.R. I-4165, para. 57. ${ }^{156} \mathrm{Id}$.

${ }^{157} \mathrm{Id}$.

${ }^{158}$ See Case C-112/00, Schmidberger v. Austria, 2003 E.C.R. I-5659, para. 81. See also Norbert Reich, How Proportionate is the Proportionality Principle? Some Critical Remarks on the Use and Methodology of the Proportionality Principle in the Internal Market Case Law of the ECJ, in THE EUROPEAN COURT OF JUSTICE AND THE AUTONOMY OF THE MEMBER STATES 83, 97-111 (Hans-W. Micklitz \& Bruno D. Witte eds., 2012) (providing an analysis of the different forms of the proportionality test).

${ }^{159}$ BARNARD, supra note 62 , at 377

${ }^{160}$ See Case C-36/02, Omega Spielhallen v. Oberbürgermeisterin der Bundesstadt Bonn, 2004 E.C.R. I-9609, paras. 14-16. The fundamental right of human dignity may be seen as an exception. Regarding the judgment, one may argue that it is being considered as an absolute right. See also Tor-Inge Harbo, The Function of Proportionality ANALYsis IN European LAW 41, 53-62 (2015) (providing an analysis of human dignity and the courts contextual approach to human dignity itself).
} 
motorway thereby closing the motorway for nearly 30 hours, was an unjustified infringement of the free movement of goods pursuant to Article 34 TFEU in conjunction with the principle of Community loyalty as now laid down in Article 4 (3) TEU. ${ }^{161}$ In this situation, it was necessary to find a balance between the right to freedom of expression and assembly and the free movement of goods. ${ }^{162}$

Needless to say, it is not practically feasible to measure the impact on fundamental rights directly. Even if there was such an instrument or at least good proxies, it remains uncertain whether a strong restriction to the free movement of goods could be justified by a slight infringement on the freedom of expression and assembly or vice versa. Thus, the courts are facing an inter-rights comparability problem that arguably may be one of the most difficult to overcome.

As cognitive illusions, such as the availability bias, apply when making decisions under such factual — and in this case additional legal — uncertainty, ${ }^{163}$ one can only imagine the impact of sensational events extensively covered by the media, such as terrorist attacks and environmental catastrophes in Western societies, on the examination of the importance of the mandatory requirements in question. Individuals, including judges, will overestimate the likelihood of such an event reoccurring and will therefore-especially in the aftermath of the event-overvalue the danger to the environment or public security. This analysis does not suggest that overall environmental protection or public security should be decreased, rather it emphasizes that human intuitions are not accurately reflecting the true probabilities and dangers to the affected goods, which can lead to a false valuation process on the importance of such goods. If anything, the behavioral sciences indicate that humans tend to value future lives much less than those of the present, casting doubt on whether humans would act differently - that is to say, support stronger environmental protection measures - if they were immune to the present bias. ${ }^{164}$ The purpose of this example is to illustrate the general fact that rare and sensational events vastly covered by the media are potential sources of the availability bias.

Though it is tough to grasp-or even prove - the extent to which judgments are based on the availability bias, it is crucial to acknowledge that the lack of proof of influences on the availability bias in specific cases does not mean that the bias did not affect the judgment. Luckily-and this is crucial to notice-it also does not signify that there are no means to mitigate such effects.

\section{Mitigating Factors}

There are a number of potential solutions to overcome the availability bias. First, several studies including those regarding judicial decision-making show that judicial experience can mitigate the availability bias. ${ }^{165}$ For example, judges performed better than students in a number of different studies focusing on the availability bias. ${ }^{166}$ But still, judges were biased to a significant extent. ${ }^{167}$

Additionally, although there are decisions to make-such as the evaluation of the potential restriction to the freedom of expression and assembly in Schmidberger - that are unfeasible to cast into numerical figures, it should be recognized that economic models may be able to evaluate the impact on fundamental freedoms. For instance, in Schmidberger, the likely effects-from an ex ante perspective - of the Brenner motorway demonstration on the market, and more particularly on the free movement of goods pursuant to Article 34 TFEU, could have been analyzed. In this matter, it seems to be a mystery why the courts are treating economic evidence differently in cases

\footnotetext{
${ }^{161}$ See generally Case 112/00, Schmidberger v. Austria, 2003 E.C.R. I-5659.

${ }^{162}$ See id. at para. 81.

${ }^{163}$ See Tversky \& Kahneman, supra note 84, at 1122.

${ }^{164}$ See Ted O’Donoghue \& Matthew Rabin, Doing It Now or Later, 89 AM. EcON. Rev. 103, 103-24 (1999).

${ }^{165}$ See Guthrie et al., supra note 4 , at 805 .

${ }^{166} \mathrm{See}$ Guthrie et al., supra note 4, at 805 .

${ }^{167}$ See Guthrie et al., supra note 4, at 805.
} 
involving matters of competition law and matters concerning the internal market. ${ }^{168}$ The obvious solution is to add economists as consultants to the courts or simply to require relevant economic or statistical evidence - at least in very important decisions - to overcome the availability bias. Of course, a set of practical issues would then arise, such as what cases are sufficiently important to require such evidence.

A more promising and realistic way to mitigate the effects of the availability bias in the near future is again to educate judges about cognitive illusions. Judicial training in behavioral economics was already suggested with regard to the anchoring affect, ${ }^{169}$ and the case for it is therefore strengthened. It should not go unnoticed that such training would be particularly beneficial with regard to the availability bias because sheer awareness of it will mitigate the effect. ${ }^{170}$

\section{Zero-Risk Bias}

\section{Introduction}

In the late 1980s, parents of small children were asked to react to the following scenario: ${ }^{171}$

(1) The insect spray you currently use costs $\$ 10$ per bottle. This spray causes 15 inhalation poisonings and 15 child poisonings for every 10,000 bottles of insect spray that are used. ${ }^{172}$

(2) You become aware of a more expensive insect spray, which would reduce the number of inhalation and child poisonings to five each for every 10,000 bottles used. How much would you be willing to pay for this spray? ${ }^{173}$

On average, parents were willing to pay an additional $\$ 2.38$ to reduce the risk by two thirds. ${ }^{174}$ But, when parents were asked what they would pay to eliminate the risk completely, they were willing to pay an additional $\$ 8.09$ on average. ${ }^{175}$ This means that to eliminate the last third of the risk, parents were willing to pay more than three times as much as they were willing to pay to eliminate two thirds of the risk. Thus, how much a parent is willing to pay to eliminate risk depends not only on the level of risk itself-such as how much the risk would decrease-but also on whether this would eliminate the risk completely. ${ }^{176}$

To explain the phenomenon, it is necessary to revisit prospect theory. Whereas any rational choice model would suggest that it does not matter whether you increase the chances of a lottery winning from $0 \%$ to $1 \%$ - or from $1 \%$ to $2 \%$-because the likelihood increases in each case by exactly $1 \%$, prospect theory is able to differ between "qualitative changes" and mere "quantitative changes." 177 The increase from $0 \%$ to $1 \%$ creates the possibility of winning, ${ }^{178}$ while the increase from $1 \%$ to $2 \%$ only makes the existing possibility more likely to happen. Similarly, the insect spray study illustrates that individuals value the elimination of a risk much higher than a mere

\footnotetext{
${ }^{168}$ Compare with Ioannis Lianos \& Christos Genakos, Econometric Evidence in EU Competition Law: An Empirical and Theoretical Analysis 61 (Ctr. L., Econ. \& Soc'y, Working Paper No. 06/12, 2012).

${ }^{169}$ See supra Section C.I.2.

${ }^{170}$ See Gerd Gigerenzer, How to Make Cognitive Illusions Disappear: Beyond "Heuristics and Biases," 2 Eur. REv. Soc. PsYCHOL. 83-115 (1991). Moreover, awareness can be used as a mitigating factor for some other biases such as the "compromise effect" - also referred to as "extremeness aversion"—or the tendency to take less extreme options if mediocre options are available.

${ }^{171}$ See W. Kip Viscusi et al., An Investigation of the Rationality of Consumer Valuations of Multiple Health Risks, 18 RAND J. ECON. 465-79 (1987) (outlining the full background and proceedings of the study).

${ }^{172}$ See id. at 471 .

${ }^{173}$ See id. at 472.

${ }^{174}$ See id. at 473.

${ }^{175}$ See id.

${ }^{176}$ See KAHNEMAN, supra note 119 , at $310-15$ (providing further examples).

${ }^{177} \mathrm{Id}$. at 311 .

${ }^{178}$ This phenomenon is also referred to as "possibility" or "lottery effect."
} 
Table 1. Average decision weights assigned to different probabilities

\begin{tabular}{|c|c|c|c|c|c|c|c|c|c|c|c|c|c|}
\hline Probability (\%) & 0 & 1 & 2 & 5 & 10 & 20 & 50 & 80 & 90 & 95 & 98 & 99 & 100 \\
\hline \multirow[t]{2}{*}{ Decision Weight } & 0 & 5,5 & 8,1 & 13,2 & 18,6 & 26,1 & 42,1 & 60,1 & 71,2 & 79,3 & 87,1 & 91,2 & 100 \\
\hline & & & \multicolumn{3}{|c|}{ Possibility Effect } & & & & \multicolumn{3}{|c|}{ Certainty Effect } & & \\
\hline
\end{tabular}

Source: Kahneman, Daniel, 2011, Thinking Fast and Slow, p. 315.

reduction of the risk, even if the reduction has a greater value in terms of expected value. ${ }^{179}$ The zero-risk bias therefore can be defined as the tendency to prefer the elimination of risk, even if alternative options produce a greater expected value. To express it differently: Individualsincluding judges - overweigh small risks and are willing to pay more than the expected value to eliminate them altogether because the decision weights that people assign to outcomes differ from the probabilities of those outcomes. ${ }^{180}$ The formula for rational decision-making by von Neumann and Morgenstern introduced earlier in this work ${ }^{181}$ therefore needs to be changed in a way so that it resembles decisions weights $\left(d_{1}, d_{2}, d_{3}, \ldots\right)$ instead of real probabilities $\left(\mathrm{p}_{1}, \mathrm{p}_{2}, \mathrm{p}_{3}, \ldots\right)$ ) if one wants to be able to predict human behavior more accurately. Consequently, the equation would state:

$$
\mathrm{U}_{\text {Expected }}=\mathrm{d}_{1} \cdots \mathrm{U}_{1}+\mathrm{d}_{2} \cdots \mathrm{U}_{2}\left(+\mathrm{d}_{3} \cdots \mathrm{U}_{3} \ldots\right)
$$

To get a sense of the deviation of decision weight and real probabilities, Table $1^{182}$ provides an overview of what decision weights individuals assign selected probabilities. Accordingly, the difference between the probability of $0 \%$ and $1 \%$ corresponds to a difference of 5.5 points in terms of decision weight. The difference between $1 \%$ and $2 \%$, however, only corresponds with a difference of 2.6 points $(8.1-5.5)$ in terms of decision weight. Thus, it confirms that individuals value the difference between $0 \%$ and $1 \%$ higher than the difference between $1 \%$ and $2 \%$.

\section{Zero-Risk Bias and the Old Debate on the Limits of Dassonville}

The zero-risk bias is, as all biases are, applicable to countless situations of judicial decision-making with regard to EU law. Due to its limited scope, this Article will concentrate on one specific and widely discussed issue, namely the ongoing discussion on the limits of the Dassonville formula. ${ }^{183}$ On the one hand, the wide scope of the free movement of goods pursuant to Article 34 TFEU based on a marketaccess approach may be understood as a great advantage from the point of view of market integration. On the other hand-as the Sunday trading cases ${ }^{184}$ and the Danish bees case ${ }^{185}$ show-such a wide interpretation of Article 34 TFEU may overload the court's capacities. Meanwhile, various ways of tackling the issue have been discussed before and after the controversial judgment in Keck \& Mithuard. ${ }^{186}$ Despite the numerous possibilities to clarify the current case law-for example, in Italy v. Commission (motorcycle trailers) ${ }^{187}$ and Mickelsson \& Roos (Jet-skies) ${ }^{188}$ _legal certainty, which still remains a general principle of EU law, is clearly suffering.

\footnotetext{
${ }^{179}$ This reduction is also referred to as the "certainty effect."

${ }^{180}$ See KAHNEMAN, supra note 119, at 315 (describing and explaining the theory in more detail).

${ }^{181}$ See supra Section B.II.

${ }^{182}$ See KAHNEMAN, supra note 119 , at 315-17.

${ }^{183}$ The formula can be found in this Article supra on page 255.

${ }^{184}$ See, e.g., Case C-145/88, Torfaen Borough Council v. B\&Q plc, 1989 E.C.R. 3851; Case C-169/91, Stoke-on-Trent City Council v. B\&Q plc, 1992 E.C.R. 6635.

${ }^{185}$ Case C-67/97, Criminal proceedings against Bluhme, 1998 E.C.R. I-08033.

${ }^{186}$ See Eleanor Spaventa, Leaving Keck Behind? The Free Movement of Goods after the Rulings in Commission v. Italy and

Mickelsson and Roos, 35 EUR. L. Rev. 914, 914-32 (2009) (providing a debate on the post-Keck case law).

${ }^{187}$ Case C-110/05, Commission v. Italy, 2009 E.C.R I-519.

${ }^{188}$ Åklagaren, Case C-142/05.
} 
Keeping in mind the human tendency to overweigh the complete elimination of a risk, the risk that EU law may not be able to cover certain measures that restrict market access may also be overvalued. ${ }^{189}$ In fact, the Court's initial concern in Keck \& Mithuard that the "tendency of traders to invoke Article 30 of the Treaty [now Article 34 TFEU] as a means of challenging any rules whose effect is to limit their commercial freedom even where such rules are not aimed at products from other Member States" is still valid. ${ }^{190}$ Despite the acknowledgement of this development, the Court came up with the rather unsatisfying judgment, distinguishing between certain selling arrangements and product requirements. ${ }^{191}$ Even in post-Keck case law, the ECJ failed to draw clear boundaries of the scope of Article 34 TFEU. In particular, any form of remoteness test that analyzes whether the link between the measure in question and the restriction to the market would be "too uncertain"192 or "too indirect"193 cannot possibly satisfy even the lowest requirements set out by the principle of legal certainty.

The only option - it is often argued - that meets a certain standard of legal certainty and is still able to avoid a situation in which the courts have to deal with the slightest restrictions to the market may be a de minimis rule. ${ }^{194}$ Not only is a de minimis rule able to set out clear boundaries, it is altogether considered the more efficient tool to protect the internal market, which is the ultimate purpose of Article 34 TFEU. While the courts would not have to deal with measures that only result into minor restrictions to the market, such as the $0.3 \%$ of the Danish territory in the Danish bees case,${ }^{195}$ the courts — given their limited resources—could deal with cases involving more significant restrictions to the free movement of goods more extensively. By doing so, the objective of Article 34 TFEU - the protection of the single market—would be pursued significantly more efficiently.

So far, so good. But what exactly does an understanding of behavioral economics add to this debate in general or to the already discussed teleological argument in particular? Indeed, the following behavioral economically informed argument must be put very carefully, as those who do not consider the efficiency of the protection of the single market as a legitimate judicial goal will have their problems with such argumentation. In fact, if one does not consider the efficiency of the judicial system as a legitimate goal—for example, due to a deontological approach to Justiceone may not buy into the following argument at all. But, if one-like most scholars-puts some value on teleological arguments, behavioral economics has something to say about Dassonville.

The ECJ, when assessing whether and how to limit the scope of the Dassonville formula, must take into account that the effect of excluding minor cases from the scope of EU law may be overvalued. More precisely, cases covering 1\% of the entire scope of Article 34 TFEU or other fundamental freedoms may be valued as covering as much as $5.5 \%$ of the scope as suggested by Table 1 above. If the court looks at the issue from the positive perspective-that is to say, what

\footnotetext{
${ }^{189}$ See KAHNEMAN, supra note 119 , at 314, 318-19 (providing an analysis of the certainty and possibility effect and their relation). One could also argue that the certainty effect applies, such as to make sure any potential restriction to the market is covered by EU law. The implications as set out by prospect theory would, however, essentially be the same.

${ }^{190}$ Joined Cases C-267/1991 \& C-268/1991, Criminal proceedings against Keck and Mithouard, 1993 E.C.R. 1-6097, para. 14.

${ }^{191}$ See id. at paras. $15-17$.

${ }^{192}$ See Case C-20/03, Burmanjer and Others, 2005 E.C.R. I-4133, para. 31. See also Case C-69/88, Krantz v. Ontvanger der Directe Belastingen, 1990 E.C.R. I-583, para. 11; Case C-418/93, Semeraro Casa v. Sindaco del Comune di Erbusco, 1996 E.C.R. I-2975, para. 32 (holding a similar conclusion concerning the freedom of establishment).

${ }^{193}$ See Case C-44/98, BASF v. Präsident des Deutschen Patentamts, 1999 E.C.R. I-6269, paras. 16, 21. See also Janja Hojnik, De Minimis Rule within the EU Internal Market Freedoms: Towards a More Mature and Legitimate Market?, 6 EUR. J. LEGAL STUD. 25, 31 (2013).

${ }^{194}$ See generally Case C-67/97, Criminal proceedings against Bluhme, 1998 E.C.R. I-08033 (rejecting a de minimis approach). See also Case C-412/93, Leclerc-Siplec v. TF1 Publicité, 1995 E.C.R. I-179, paras. 195-96. AG Jacobs seems to be in favor of such a rule given his analysis stating that the relevant factor should be whether there is a "substantial restriction on [market] access" for academic support. See also Stephen Weatherill, After Keck: Some Thoughts on How to Clarify the Clarification, 33 COMMON MKT. L. REV. 887, 887-908 (1996) (providing further references).

${ }^{195}$ See generally Case C-67/97, Criminal proceedings against Bluhme, 1998 E.C.R. I-08033.
} 
cases may be covered instead of looking at what cases may not be covered-the effect would be even greater. As Table 1 indicates, a reduction of the scope to $99 \%$ of the current Dassonville level may be valued as a reduction to $91.2 \%$. Thus, cases not covered from the point of view of the Court would amount to $8.8 \%$, instead of only $1 \%$. Hence, whichever way the Court looks at the reduction-whether from the positive or negative perspective-it will overestimate the number of cases excluded due to a potential de minimis rule. ${ }^{196}$

If one now takes into account that the zero-risk bias may reasonably be a strong driving force behind supporting arguments against a de minimis rule, the trustworthiness of the underlying intuitions can be seriously questioned. In case one does not put any value on teleological arguments and strongly opposes any de minimis rule in principle, one may not be convinced by this analysis. Yet, if one is generally open towards the teleological approach, but intuitively considers the number of potentially excluded cases as too high, it must be asked whether this intuition can be explained by the zero-risk bias and should therefore not be trusted. Consequently, taking into account the zero-risk bias when analyzing the limits of Dassonville does not necessarily create a substantial new argument per se, rather it suggests that the risks or downsides of a de minimis rule may be much smaller than expected. For this reason, the argument for the teleological approach of efficiently protecting the internal market may be undervalued overall and should instead be given greater meaning.

\section{Hindsight Bias}

\section{Introduction}

The hindsight bias ${ }^{197}$ was discovered by Baruch Fischhoff and Ruth Beyth, who conducted a survey before the president of the United States at the time, Richard Nixon, visited Russia and China in early $1972 .{ }^{198}$ Participants were asked to estimate the likelihood of 15 different scenarios, such as whether the United States and Russia would agree on anything significant or whether Mao Zedong would agree to meet Nixon. ${ }^{199}$ After Nixon returned, participants were asked to recall the probabilities that they assigned to each scenario as accurately as they could. ${ }^{200}$ The outcome was clear: Subjects assigned scenarios that actually took place much higher probabilities than they initially did, while events that did not happen were assigned lower probabilities than before. ${ }^{201}$ To put it briefly, the hindsight bias is the inclination to perceive events that have already occurred as being more predictable than they actually were before they took place. ${ }^{202}$ Further studies indicate that the bias occurs because people update their beliefs about the world as soon as they become aware of a certain outcome. ${ }^{203}$

\footnotetext{
${ }^{196}$ Admittedly, one might argue there are two different phenomena at stake. While the above-mentioned studies consider the likelihood of an event occurring, a de minimis rule is about the scope of the Dassonville formula. Yet, given that the human brain seems to process information in a more general way, there is no reason to assume that human cognition is better suited to think about probabilities when it comes to the scope of $x$ than to the likelihood of $x$ happening. The decisive part is that actual and perceived probability systematically differ.

${ }^{197}$ Also referred to as the knew-it-all-along effect, outcome bias, or creeping determinism.

${ }^{198}$ See Baruch Fischhoff \& Ruth Beyth, "I Knew it Would Happen" - Remembered Probabilities of Once-Future Things, 13 Org. Behav. \& Hum. Performance 1, 1-16 (1975). See also Baruch Fischhoff, Hindsight $\neq$ Foresight: The Effect of Outcome Knowledge on Judgment Under Uncertainty, 1 J. Experimental Psychol.: Hum. Perception \& PerformanCE 288, 288-99 (1975).

${ }^{199}$ See Fischhoff \& Beyth, supra note 198, at 6.

${ }^{200}$ See Fischhoff \& Beyth, supra note 198, at 6.

${ }^{201}$ See Fischhoff \& Beyth, supra note 198, at 6.

${ }^{202}$ See Neal J. Roese \& Kathleen D. Vohs, Hindsight Bias, 7 PersP. Psychol. ScI. 411, 411-26 (2012).

${ }^{203}$ See Scott A. Hawkins \& Reid Hastie, Hindsight: Biased Judgments of Past Events After the Outcomes Are Known, 107 Psychol. Bull. 311, 313 (1990).
} 


\section{Hindsight Bias, Schmidberger, and the Remoteness Test}

Because judges usually evaluate events after they have already occurred, they are particularly vulnerable to the hindsight bias. ${ }^{204}$ Due to the significance of the proportionality test within EU law, ${ }^{205}$ the decisive question is often whether the measure under consideration was suitable and necessary to achieve its aim, thereby taking an ex ante perspective. For instance, in Schmidberger, the ECJ had to assess the impact that the closing of the Brenner motorway had on the free movement of goods from the perspective of the Austrian authorities at the time, before the actual closure happened. Nevertheless, the Court argued that "in the present case various administrative and supporting measures were taken by the competent authorities in order to limit as far as possible the disruption to road traffic." ${ }^{206}$ Yet, whether such supporting measures had been taken at the time of the demonstration is irrelevant if those measures were not required or foreseen when authorizing the closure of the motorway, for this argument is based on the actualrather than expected - outcome of the initial closing of the highway. In fact, it does not matter whatsoever whether the impact on the fundamental freedom of the free movement of goods was less than one could have expected. It merely matters whether-at the time of the authorizationone could expect that such matters would be undertaken and, therefore, expect that the restriction to Article 34 TFEU would be limited to a certain extent.

Similarly, any form of a remoteness test used to determine whether a measure falls within the ambit of Article 34 TFEU will face significant problems due to the hindsight bias, as judges are not able to evaluate whether an outcome can be sufficiently connected to the effects of the measure in question if they are already aware of the actual outcome. In fact, applying the hindsight bias would suggest that the European courts will overvalue the causal link between the actual outcome and the measure being considered. This inevitably causes a too-rare application of the remoteness test which can be empirically supported by pointing out that the remoteness question is not even discussed in most cases. ${ }^{207}$ Even in cases in which the issue is either raised by the parties involved or by state submissions, the Court still prefers to avoid getting into a detailed analysis of the test. ${ }^{208}$ If the test is applied, Shuibhne notes that "questions of causal connection seem ... to be assumed rather than tested in free movement case law." 209 Without proper statistical analysis, however, it is not possible to avoid the hindsight bias. Contrary to what the analysis of the availability bias and anchoring effect may suggest, even many years of legal experience combined with advanced knowledge about the hindsight bias are not able to function as a mitigating factor. ${ }^{210}$

Because people are vulnerable to the hindsight bias even when they are aware of it, a potential solution to the issue would require that those who analyze the causal connection under consideration are not aware of the actual outcome-regardless of whether this involves the remoteness test or questions of suitability and necessity. The person cannot know what actually happened and must analyze the situation merely by looking at the measure and what could potentially happen or not. Thus, one may argue that judges already involved in the case are not in the best position to analyze causal connections from relevant past events.

Provided that a clear economic or statistical analysis is not possible, it seems advisable to conduct surveys asking participants - who are not aware of the actual outcome- what effects the measure in question might have or whether it could restrict market access. The questions and their exact

\footnotetext{
${ }^{204}$ See Rachlinski, supra note 70, at 588-90. See also Guthrie et al., supra note 4, at 825.

${ }^{205}$ See supra Section C.II.3.

${ }^{206}$ Case C-112/00, Schmidberger v. Austria, 2003 E.C.R. I-5659, para. 87.

${ }^{207}$ See Niamh Nic Shuibhne, The Outer Limits of EU Citizenship: Displacing Economic Free Movement Rights?, in THE Outer Limits of European LaW 179 (Catherine Barnard \& Okeoghene Odudu eds., 2009).

${ }^{208}$ See Niamh Nic Shuibhne, The Coherence of EU Free Movement Law: Constitutional Responsibility and the COURT OF JUSTICE 182 (2013).

${ }^{209} I d$.

${ }^{210}$ See Rachlinkski, supra note 70, at 586-88. See also Rüdiger F. Pohl \& Wolfgang Hell, No Reduction in Hindsight Bias after Complete Information and Repeated Testing, 67 Org. Behav. \& Hum. DeCision Processes 49, 49-58 (1996).
} 
framing must be carefully assessed in each case, however, given the strong effect of the hindsight bias and the overarching importance of some of the cases decided by the European courts, the establishment of such an "unbiased jury" for the investigation of specific causal connections might be beneficial. Although research suggests that judges could also mitigate the hindsight bias by thinking about alternative outcomes — as was already suggested regarding the anchoring effect ${ }^{211}$ —an unbiased jury would not only be able to mitigate but even eliminate the hindsight bias. ${ }^{212}$ If such an approach will not be valued as a feasible improvement to the courts decision-making procedures, then it further strengthens the case for judicial training in behavioral economics.

\section{Concluding Remarks}

The Article started by introducing the major claims of behavioral economics, thereby focusing particularly on different aspects of prospect theory and how rational decision-making models based on the assumption of the homo economicus deviate from actual choices made by individuals. Because heuristics and biases are closely linked to the different functions of System 1 and System 2 thinking, experts-including judges - are also subject to cognitive illusions.

In the next part of this Article, the value of taking into account behavioral economics when making judicial decisions in EU law was demonstrated by analyzing the impact of selected biases to diverse legal issues, as well as offering potential solutions for overcoming or mitigating cognitive illusions. More specifically, the following was proposed:

I. Judicial training pertaining to behavioral economics should be provided to mitigate cognitive illusions, such as the anchoring effect, availability, and hindsight bias. Because it does not seem feasible to cover all potential sources of cognitive illusions, the training should not only focus on specific applications of various biases, but it should also outline how and under what circumstances such biases may occur in general. As discussed above, sheer awareness can often be a first step to mitigate biases, but more specific techniques, such as thinking about alternative solutions in order to reduce the anchoring effect, are also crucial.

II. If possible, the courts should increase the amount of economic and statistical evidence necessary to mitigate different biases such as the availability and hindsight bias with particular regard to the proportionality test. As indicated in the analysis of the Schmidberger judgment, the tool has its limits when fundamental rights are at stake. Yet, when balancing different fundamental freedoms, it may be a significant means to overcome biases.

III. On a more specific note, the analysis of the zero-risk bias has indicated that an extensive scope of the fundamental freedoms may be overvalued because the amount of cases that are not covered by EU law may be considerably less than one can intuitively grasp. After analyzing what restrictions to the market shall be covered, a clear de minimis rule to all fundamental freedoms in EU law would not only avoid future zero-risk biases, but also raise legal certainty. Also, the financial means that go into cases with the tiniest restrictions to the internal market may be better spent on statistical evidence in more significant cases and judicial training, thereby protecting the single market more efficiently.

IV. Last, but certainly not least, the analysis of causal connections from an ex ante perspective, as required within the proportionality test or by any form of remoteness test, will be strongly influenced by the hindsight bias. For this reason, the Article suggested the establishment of an unbiased jury consisting of individuals who are not aware of the actual outcomes of the case. This having said, more research is essential to develop the exact conditions for such an endeavor to succeed.

\footnotetext{
${ }^{211}$ See Hal R. Arkes et al., Eliminating Hindsight Bias, 73 J. ApPLIED PsYCHOL. 305, 305-07 (1988).

${ }^{212}$ See Guthrie et al., supra note 4, at 826 (providing a more general discussion on the (dis-)advantages of juries from a behavioral perspective).
} 
All in all, the examination of only a few of the many potential shortcomings in human thinking regarding judicial decision-making has underlined the importance of taking into account behavioral economic findings. By focusing on a small number of cognitive biases, their effects in certain scenarios, and on understanding selected cases, the analysis indicated that there is much left to explore. The recommendations made should, therefore, merely be regarded as first steps, rather than as ultimate solutions to improve judicial decision-making in the European Courts.

Regarding second steps, one needs to keep in mind that human abilities are limited both in physical and mental terms. For thousands of years, technology has been focusing on tackling the obvious, physical limits. Some of the proposals made may help to overcome or avoid some of our cognitive limitations. But, while some biases can be mitigated to some extent with different techniques, it does not seem feasible to eliminate them completely. Relying on natural intelligence will likely never guarantee flawless judgments. Despite bearing fundamental risks, artificial intelligence may provide means to achieve greater fairness, consistency, and legal certainty in the future. 